\title{
FREQUENCY, CLINICAL FEATURES AND RESPONSE TO TREATMENT OF INFECTED ASCITES AT AIN SHAMS UNIVERSITY HOSPITALS
}

\author{
By \\ SANAA MOHARAM KAMAL, SARA MAHMOUD ABDELHAKAM, DALIA \\ GHORABA*, YASMINE MAHMOUD MASSOUD, KAREEM ABD EL AZIZ ABD EL \\ HAFEEZ, SAFAA TAWFIC RAGAB, and HAZEM AHMED KAMAL
}

Department of Tropical Medicine, Faculty of Medicine, Ain Shams University, Cairo 11566, Egypt ( ${ }^{\star}$ Correspondence: dr.daliaghoraba@yahoo.com)

\section{Abstract}

Ascites is a common problem in patients with chronic liver disease. About $60 \%$ of patients with cirrhosis will develop ascites. Patients with chronic liver disease and cirrhosis frequently develop infections of the ascitic fluid. This study assessed the clinical profile of patients with ascitic fluid infection admitted to Tropical Medicine department at Ain Shams University hospitals. The cross-sectional study was conducted on 87 Egyptian patients with chronic liver disease and ascites over one year from June 2017 to May 2018 by collecting their clinical, laboratory and radiological data. The frequency of infected ascites among the studied patients with chronic liver disease and ascites was $31 \%$. The main presenting symptom was abdominal pain (37\%) and the most common clinical sign was lower limb edema $(81 \%)$. The most frequently isolated micro-organism was $E$. coli detected in $7 \%$ of patients with infected ascites. Among the 27 patients with infected ascites, 12 patients responded to the $3^{\text {rd }}$ generation cephalosporins, nine patients responded to Meropenem.

Keywords: Ascites, Spontaneous bacterial peritonitis, Ascitic fluid infection.

\section{Introduction}

Ascites is a common problem in patients with chronic liver disease. About $60 \%$ of patients with cirrhosis will develop ascites (Gineset al., 2010). The main pathophysiology of ascites is progressive increase in portal venous pressure as a result of increased intrahepatic resistance caused by cirrhosis (Brett and Andres, 2017). Portal hypertension increases the hydrostatic pressure at the sinusoidal level and causes some hemodynamic changes including the splanchnic vasodilatation, reduced systemic resistance, increased plasma volume and cardiac output. These alterations stimulate the renin-angiotensin-aldosterone system leading to renal sodium and water retention that result in ascites (Gentilini and Laffi, 1992).

Patients with chronic liver disease and cirrhosis frequently develop infections of the ascitic fluid. Spontaneous bacterial peritonitis (SBP) is an ascitic fluid infection without an evident intraabdominal surgically treatable source, primarily occurred in patients with advanced cirrhosis (Sheer and Runyon, 2005). Diagnosis was established by positive ascitic fluid examination bacterial culture and elevated ascitic fluid absolute polymor- phonuclear leukocyte (PMN) count $(\geq 250$ cells $/ \mathrm{mm}^{3}$ ). SBP occurs in one third of patients with cirrhosis and is associated with hospital mortality of $20 \%$ to $40 \%$, patients recovered an attack of SBP had an increased risk of recurrence of $40 \%$ to $70 \%$ in one year and poorer survival on follow-up (Sheer and Runyon, 2005).

Other variants of ascitic fluid infections include culture-negative neutrocytic ascites, monomicrobial non-neutrocyticbacterascites and polymicrobialbacterascites. These variants of infected ascites were distinguished from classic SBP largely by ascitic fluid and it is important to recognize these variants in at-risk patients who did not fulfill classical definitions of SBP (Runyon, 2009)

Bacterial isolates in SBP differed from the isolates detected in neutrocytic ascites, monomicrobial non-neutrocyticbacterascites and polymicrobialbacterascites. Gram-negative organisms are the most common organisms in SBP (Fiore et al, 2017).

Third generation cephalosporins are commonly used as empirical treatment of infected ascites with cirrhosis as they cover both enterobactericae and non-enterococcal streptococci (Fernandz and Gustot, 2012). The 
development of multidrug resistant strains raise the need to investigate other antibiotic regimen based on the prevalence and the antimicrobial resistance pattern of the infection (Juan, 2015).

The aim of this study was to assess the frequency, clinical profile, bacteriological patterns and outcome of spontaneous bacterial peritonitis and other variants of ascitic fluid infections in patients of liver cirrhosis admitted to Tropical Medicine department at Ain Shams University hospitals. The study will also aim to investigate the bacterial isolates and antibiotic sensitivity and resistance patterns in different variants of ascitic fluid infections.

\section{Patients and Methods}

This cross-sectional study enrolled 87 patients with chronic liver disease and ascites with ages more than 18 years old admitted to Tropical Medicine Department, Ain Shams University hospitals from June 2017 to May 2018. The study was approved by the Ethical Committee of Faculty of Medicine, Ain Shams University. An informed consent was obtained from each patient or his relatives prior to enrollment

The patients fulfilled the following criteria, fever, abdominal tenderness, leukocytosis, elevated CRP, ascitic cell count $>250$ cells/ $\mathrm{mm} 3$ or positive ascitic culture and sensitivity tests. Those patients received empirical antibiotics in the form of third generation cephalosporins till the result of the ascitic culture and sensitivity (group A). Monitoring of the response was guided by improvement of clinical signs (fever and abdominal tenderness) and improvement of ascitic cell count taken after 48 hours from the start of antibiotic treatment .Age and gender matched patients with no evidence of infected ascites were included in the study as control group (group B).

Patients with other causes of ascites other than chronic liver disease as tuberculous or malignant ascites and patients who received antibiotics one week prior to hospital admission were excluded.
All patients and control subjects were subjected to complete clinical history with special focus on abdominal pain, fever, history of ascetic fluid infection, history of recent tapping in last month, deteriorated level of consciousness and any previous endoscopic maneuvers for intervention for esophageal varices.

Physical examination stressed on signs of chronic liver disease and portal hypertension like hepatomegaly and splenomegaly, fever, jaundice, and lower limb edema, signs of hepatic encephalopathy, grade of ascites and, abdominal tenderness and rebound tenderness.

Laboratory investigations included complete blood picture, liver functions profile (including coagulation profile, liver enzymes, serum albumin and serum bilirubin)., renal profile including serum creatinine, serum sodium and serum potassium levels and ascitic fluid analysis: comprising ascetic fluid cell count, assessment of ascetic fluid glucose, proteins, albumin, LDH and culture and sensitivity of the ascetic fluid.

Abdominal ultrasonography was performed to all patients to assess organomegaly, ascites, and internal echoes of ascitic fluid, hepatic focal lesion and patency of portal vein, hepatic veins and inferior vena cava.

Statistical analysis: Data were analyzed by using Student t-tests, ANOVA or KruskallWallis test as appropriate for continuous variables and Chi-square or Fisher's exact tests were used for categorical variables. Bacterial counts were examined in box-plots as continuous variables. A Kruskal-Wallis one-way analysis of variance test tested for a significant overall shift in bacterial levels in cases and controls and the Mann-Whitney $U$-test examined identified sample pairs. Comparison of bacterial counts before and after antibiotic treatment will be assessed by Paired t-test. Pearson $r$ correlation test was used to assess the relation between bacterial strain and ascetic fluid infection variant. Logistic regression was used to predict ascites infection in patients with liver disease. Results were expressed as 
mean \pm S.D (SPSS version 22 (SPSS, IBM Inc., NC, USA) and GraphPad Prism software (GraphPad Software Inc., CA, USA).

\section{Results}

Patients after initial screening for criteria of infection of ascites were classified into the study group which included 27 patients with infected ascites and 60 patients with non-infected ascites were included as control group. There was no significant difference in age between the two study groups (mean age in group A was 52.11 \pm 12.99 years old and in group B, it was 53 \pm 54.77 years). Among studied patients in group A, 17 patients were males $(63 \%)$ and 10 patients were females (37\%) and in group B 36 patients were males $(60 \%)$ and 24 patients were females (40\%). Chronic hepatitis C and HCV related cirrhosis was the primary liver disease etiology in the majority of enrolled patients 59 (67.82\%) patients

Many patients had previous history of SBP compared to patients in control group where the percentage of patients who had history of SBP in study and control groups were $11 \%$ and $5 \%$, respectively but without statistical significance (Tab.1). Fever and abdominal pain were significantly detected in study group. A highly significant difference was observed between the two groups in the occurrence of fever, abdominal pain and tenderness, lower limbs edema, grade of ascites. The patients who had fever was $30 \%$ in study group versus $3 \%$ in control group. Abdominal tenderness and rebound tenderness were reported in $37 \%$ and $3 \%$ of patients in study groups and control groups respectively. Lower limb edema was detected in $81 \%$ in study group and $23 \%$ in control group. Also, the percentage of patients who had tense ascites was $78 \%$ in study group and $33 \%$ in control group, with significant difference between the two groups in total white blood cell count, and significant differences were observed between the two studied groups in total and direct serum bilirubin. Serum albumin was significantly lower in study group than in control group among the studied patients. A statistical significant difference between both groups was in INR and $\mathrm{C}$ reactive protein significantly higher than in control (Table 2).

The portal vein, hepatic vein and inferior vena cava were assessed in the two groups, however, no statistically significant differences were found in any of the three parameters (data not shown). A statistical significant difference between the two groups was observed in both ascitic fluid LDH and glucose. The ascitic cell count and ascitic fluid LDH were significantly higher in study group than in control group, while ascitic fluid glucose was significantly lower in study group than in control group (Tab. 3). The various isolated microorganisms and the antibiotics according to culture and sensitivity given in (Tab. 4). The most common isolated organism was Escherichia coli (E. coli) was isolated in two patients (7\%), while each of the other organisms (Staph Coag Neg, Actinobacter spp., Strept. Viridans, Non-hemolytic strept and MRSA / Enterococci) was isolated in one patient (4\%). Our study on the 27 patients with ascitic fluid infection showed significant improvement in ascitic fluid cell count $48 \mathrm{hrs}$ after starting antibiotic treatment where 12 patients (44\%) responded to the third generation cephalosporins and 9 patients (33\%) responded to Meropenem (4 of them were resistant to the $3^{\text {rd }}$ generation cephalosporins), 2 patients received Meropenem based on results of ascitic culture and sensitivity and 3 patients received Meropenem empirically (because they had nosocomial ascitic fluid infection), 3 patients (11\%) responded to culture-based Linezolide and one patient responded to culturebased Ciprofloxacin, one patient was resistant to the third generation cephalosporin and responded to Piperacillin/Tazobactam and one patient was asymptomatic Nonneutrocytic bacterascites who did not receive antibiotic treatment. 
Table 1: History, clinical manifestations and etiology of liver disease of enrolled patients and controls

\begin{tabular}{|l|c|c|c|}
\hline & Patients (N=27) & Control (N=60) & P value \\
\hline Parameter (No\%) & $3(11)$ & $3(5)$ & 0.3690 \\
\hline Previous history of SBP; n (\%) & $9(33)$ & $25(42)$ & 0.4880 \\
\hline History of recent tapping in last month; $\mathrm{n}(\%)$ & $8(30)$ & $2(3)$ & $0.0133^{* *}$ \\
\hline Fever; $\mathrm{n}(\%)$ & $7(26)$ & $8(13)$ & 0.2185 \\
\hline Encephalopathy; n (\%) & & & \\
\hline Jaundice; (\%) & $10(37)$ & $15(25)$ & 0.3081 \\
\hline Abdominal pain; n (\%) & $10(37)$ & $2(3)$ & $<0.0001^{* *}$ \\
\hline Fever & $8(30)$ & $2(3) * * *$ & $<0.0001^{* *}$ \\
\hline Lower limb edema & $22(81)$ & $14(23)$ & $<0.0001^{* *}$ \\
\hline Enlarged liver & $16(59)$ & $31(52)$ & 0.6428 \\
\hline Enlarged spleen & $11(41)$ & $23(38)$ & 1.0000 \\
\hline Grade of ascites :Moderate & $6(22)$ & $40(67)$ & $0.0002^{* *}$ \\
:Tense & $21(78)$ & $20(33)$ & $<0.001^{* *}$ \\
\hline Abdominal tenderness \&rebound tenderness & $10(37)$ & $2(3) \# \#$ & $<0.0001^{* *}$ \\
\hline HCV & $18(66)$ & $41(68)$ & 1.0000 \\
HBV & $2(7)$ & $1(2)$ & 0.2263 \\
BCS & $3(11)$ & $14(23)$ & 0.2480 \\
Schistosomiasis & $1(4)$ & $0(0)$ & 0.3103 \\
Autoimmune & $0(0)$ & $3(5)$ & 0.5491 \\
HCV\&HBV & $1(4)$ & $1(2)$ & 0.5269 \\
HCV\&Schistosomiasis & $1(4)$ & $0(0)$ & 0.3103 \\
Not diagnosed & $1(4)$ & $0(0)$ & 0.3103 \\
\hline
\end{tabular}

Table 2: Laboratory functions in groups.

\begin{tabular}{|c|c|c|c|}
\hline Variables & Group & Mean \pm Std. Deviation & $\mathrm{P}$ value \\
\hline \multirow{2}{*}{$\begin{array}{l}\text { White blood cells count } \\
\left(4-10 * 10^{\wedge} 3 / \mathrm{ul}\right)\end{array}$} & Study group $(\mathrm{N}=27)$ & $9.1481 \pm 2.95832$ & \multirow{2}{*}{$.005^{*}$} \\
\hline & control $(\mathrm{N}=60)$ & $6.7083 \pm 2.81680$ & \\
\hline \multirow{2}{*}{$\begin{array}{l}\text { PML \% } \\
(50-80 \%)\end{array}$} & Study group $(\mathrm{N}=27)$ & $70.4308 \pm 10.26321$ & \multirow{2}{*}{0.19} \\
\hline & Control $(\mathrm{N}=60)$ & $67.1368 \pm 10.64352$ & \\
\hline \multirow{2}{*}{$\begin{array}{l}\text { Hemoglobin } \\
(12-15 \mathrm{~g} / \mathrm{dl})\end{array}$} & Study group $(\mathrm{N}=27)$ & $10.2556 \pm 2.36193$ & \multirow{2}{*}{0.78} \\
\hline & control $(\mathrm{N}=60)$ & $10.9517 \pm 2.05092$ & \\
\hline \multirow{2}{*}{$\begin{array}{l}\text { Platelet } \\
\left(150-410 * 10^{\wedge} 3 / \mathrm{ul}\right)\end{array}$} & Study group $(\mathrm{N}=27)$ & $166.2963 \pm 12.09709$ & \multirow{2}{*}{0.81} \\
\hline & Control(N=60) & $159.0167 \pm 17.59383$ & \\
\hline \multirow{2}{*}{$\begin{array}{l}\text { Total serum bilirubin }(0.3-1 \\
\mathrm{mg} / \mathrm{dl})\end{array}$} & Study Group : N=27 & $4.7037 \pm 1.84456$ & \multirow[t]{2}{*}{$.045^{*}$} \\
\hline & Control Group : $\mathrm{N}=60$ & $2.7300 \pm 1.19631$ & \\
\hline \multirow{2}{*}{$\begin{array}{l}\text { Direct bilirubin } \\
\text { (up to } 0.2 \mathrm{mg} / \mathrm{dl} \text { ) }\end{array}$} & Study Group : N=27 & $3.2308 \pm 1.93891$ & \multirow{2}{*}{$.005^{*}$} \\
\hline & Control Group : $\mathrm{N}=60$ & $1.3867 \pm 0.26671$ & \\
\hline \multirow{2}{*}{$\operatorname{AST}(13-39 \mathrm{U} / \mathrm{L})$} & Study Group : N=27 & $102.3333 \pm 12.90333$ & \multirow{2}{*}{.289} \\
\hline & Control Group : N=60 & $78.2717 \pm 8.81394$ & \\
\hline \multirow{2}{*}{$\operatorname{ALT}(7-52 \mathrm{U} / \mathrm{L})$} & Study Group : N=27 & $42.3704 \pm 5.26677$ & \multirow{2}{*}{.972} \\
\hline & Control Group : $\mathrm{N}=60$ & $41.9333 \pm 5.35295$ & \\
\hline \multirow{2}{*}{$\begin{array}{l}\text { Total serum } \\
\text { Proteins }(6-8.3 \mathrm{~g} / \mathrm{dl})\end{array}$} & Study Group : N=27 & $6.2571 \pm 1.33288$ & \multirow{2}{*}{.646} \\
\hline & Control Group : N=60 & $6.4026 \pm 1.05151$ & \\
\hline \multirow{2}{*}{$\begin{array}{l}\text { Serum Albumin } \\
(3.5-5.7 \mathrm{~g} / \mathrm{dl})\end{array}$} & Study Group : N=27 & $2.1852 \pm 0.42940$ & \multirow{2}{*}{$.016^{*}$} \\
\hline & Control Group : $N=-60$ & $2.4517 \pm 0.53851$ & \\
\hline \multirow{2}{*}{$\begin{array}{l}\text { BUN } \\
(5-23 \mathrm{mg} / \mathrm{dl})\end{array}$} & Study Group : N=27 & $26.307 \pm 8.340$ & \multirow{2}{*}{0.834} \\
\hline & Control Group : $N=60$ & $27.59 \pm 8.269$ & \\
\hline \multirow{2}{*}{$\begin{array}{l}\text { Creatinine } \\
(0.6-1.2 \mathrm{mg} / \mathrm{dl})\end{array}$} & Study Group : N=27 & $1.4444 \pm 0.01955$ & \multirow{2}{*}{0.536} \\
\hline & Control Group : $\mathrm{N}=60$ & $1.8767 \pm 0.16522$ & \\
\hline \multirow{2}{*}{$\begin{array}{l}\text { Sodium } \\
(136-145 \mathrm{mmol} / \mathrm{l})\end{array}$} & Study Group : N=27 & $132.3333 \pm 5.51222$ & \multirow{2}{*}{0.211} \\
\hline & Control Group : $\mathrm{N}=60$ & $129.1983 \pm 17.41558$ & \\
\hline Potassium (3.5- $5.1 \mathrm{mmol} / \mathrm{l})$ & Study Group : N=27 & $5.5852 \pm 1.71406$ & 0.778 \\
\hline \multirow{2}{*}{$\begin{array}{l}\text { INR } \\
(0.8-1.2)\end{array}$} & Study Group : N=27 & $1.8822 \pm 0.11124$ & \multirow[t]{2}{*}{$.019^{*}$} \\
\hline & Control Group : N=60 & $1.5118 \pm 0.2030$ & \\
\hline \multirow{2}{*}{$\begin{array}{l}\text { C-reactive Protein } \\
(<6)\end{array}$} & Study Group : N=27 & $59.0200 \pm 4.87468$ & \multirow{2}{*}{$.036^{*}$} \\
\hline & Control Group : N=60 & $24.1943 \pm 9.3091$ & \\
\hline
\end{tabular}

**Highly significant: $<0.01,0.000, *$ Significant difference 
Table 3: Ascitic fluid analysis.

\begin{tabular}{|c|c|c|c|}
\hline Parameter & Group & Mean \pm SD & $\mathrm{P}$ value \\
\hline \multirow{2}{*}{$\begin{array}{l}\text { Ascitic fluid cell count } \\
(>250 \text { cells } / \mathrm{mm} 3)\end{array}$} & Study Group : N=27 & $549.8519 \pm 64.67823$ & \multirow{2}{*}{$0.007 * *$} \\
\hline & Control Group : N=60 & $58.35596 \pm 4.10088$ & \\
\hline \multirow{2}{*}{$\begin{array}{l}\text { Follow-up ascitic fluid cell count } \\
(<250 \text { cells } / \mathrm{mm} 3)\end{array}$} & Study Group : N=27 & $95.73919 \pm 8.77809$ & \multirow{2}{*}{$0.004 *$} \\
\hline & Control Group : $\mathrm{N}=60$ & $58.35596 \pm 4.10088$ & \\
\hline \multirow{2}{*}{$\begin{array}{l}\text { Ascitic fluid protein } \\
\text { (Transudate }<3 \mathrm{~g} / \mathrm{dl} \text {, Exudate }>3 \mathrm{~g} / \mathrm{dl} \text { ) }\end{array}$} & Study Group : N=27 & $1.540 \pm 0.81$ & \multirow{2}{*}{0.213} \\
\hline & Control Group : $\mathrm{N}=60$ & $13.858 \pm 1.01$ & \\
\hline \multirow[t]{2}{*}{ Ascitic fluid albumin $(\mathrm{g} / \mathrm{dl})$} & Study Group : N=27 & $1.54 \pm 0.48$ & \multirow[t]{2}{*}{0.127} \\
\hline & Control Group N=60 & $0.7800 \pm 0.2864$ & \\
\hline \multirow[t]{2}{*}{ Ascitic fluid LDH (IU/L) } & Study Group : N=27 & $179.5304 \pm 41.65863$ & \multirow{2}{*}{$0.0490 *$} \\
\hline & Control Group N=60 & $79.8610 \pm 5.29765$ & \\
\hline \multirow{2}{*}{ Ascitic fluid glucose (mg/dl) } & Study Group : N=27 & $118.4870 \pm 16.08609$ & \multirow{2}{*}{$0.013 *$} \\
\hline & Control Group $\mathrm{N}=60$ & $144.6883 \pm 20.58725$ & \\
\hline
\end{tabular}

*Statistically significant difference

Table 4: Isolated microorganisms and their antibiotic sensitivity in patients.

\begin{tabular}{|l|l|l|}
\hline Parameter (No. /\%) & Group A (N:14) & Antibiotic \\
\hline Organisms in ascitic culture \& sensitivity: & & Ceftriaxone and \\
E-coli & $2(7)$ & Meropenem \\
Staph Coag. Neg. & $1(4)$ & Linezolide \\
Actinobacter spp. & $1(4)$ & Not given* \\
Strept. Viridans & $1(4)$ & Meropenem \\
Non-hemolytic strept & $1(4)$ & Ciprofloxacin \\
MRSA / Enterococci & $1(4)$ & Linezolide \\
\hline
\end{tabular}

\section{Discussion}

Generally speaking, HCV represents a global health problem with $\sim 200$ million individuals currently infected, worldwide. With the high cost of antiviral therapies, the global burden of chronic hepatitis $\mathrm{C}$ infection $(\mathrm{CHCV})$ infection will be substantially reduced by the development of an effective vaccine for $\mathrm{HCV}$. In the present study, the mean age of the patients with infected ascites was $52.11 \pm 12.99$ years old. This was consistent with Schwabl et al. (2015) who reported that $73.8 \%$ of patients with ascitic fluid infection (AFI) were males and $26.2 \%$ were females with mean age was $56.67 \pm 11.28$ years old. The HCV was the most common etiology of chronic liver disease in 18 patients (66\%) with infected ascites. But, Schwabl et al. (2015) reported that the majority of patients had alcoholic cirrhosis (52\%) and 22\% only had viral hepatitis. However, the present results were consistent with Abdella et al. (2016) who reported that the most common etiological cause among the Egyptian patients admitted at Ain Shams University hospitals with AFI was HCV infection that was detected in $83.5 \%$ of studied patients.
The present study showed that the main presenting symptom of infected ascites was abdominal pain (37\%). This was less evident than Abdella et al. (2016) who reported $83.5 \%$ abdominal pain. In the current study, lower limb edema was in $81 \%$ of patients on general examination. This agreed with Abdella et al. (2016) who reported that lower limb edema was the most common clinical sign $(84 \%)$. Other symptoms and signs of infected ascites were frequent jaundice in patients with and without infected ascites, as well as fever and hepatic encephalopathy. This was consistent with Abdella et al. (2016) who reported that fever and hepatic encephalopathy was in $31.8 \%$ \& $43.5 \%$ of cases respectively.

In the present study, the total leukocytic count was significantly higher in patients with infected ascites $\left(9.1510^{\wedge} 3 / \mathrm{ul}\right)$ than in those without infected ascites $\left(6.7110^{\wedge} 3 / \mathrm{ul}\right)$. This agreed with Schwabl et al. (2015) who reported that total leukocytic count was 7.88 among the patients with infected ascites and 7.13 among those without infected ascites.

The present study showed that total bilirubin and direct bilirubin were significantly 
higher in patients with ascetic fluid infection (AFI) (T.bil4.7 \pm 5.84 , D.bil 3.23 \pm 3.94 ) than in those without infected ascites (T.bil2. $73 \pm 3.2$, D.bil $1.39 \pm 1.97$ ). The serum albumin was significantly lower in patients with AFI (2.19 \pm 0.43$)$ than in those without infected ascites $(2.45 \pm 0.54)$. This also agreed with Schwabl et al. (2015) who found that total bilirubin and serum albumin were about $3.75 \& 2.73 \pm 6.06$ respectively among the AFI patients. But, in contrast to the present results, the total bilirubin and serum albumin levels did not significantly differed from the levels in patients without infected ascites (3.24 \& 2.7 \pm 5.46$)$ respectively. More over, the present results agreed with $\mathrm{Ba}-$ dawy et al. (2013) among one hundred Egyptian patients with AFI found the total bilirubin, direct bilirubin and serum albumin were about 5.22, $3.26 \& 2.17$ respectively.

In the present study, INR and CRP were significantly higher in patients with AFI than in patients without infected ascites. Schwabl et al. (2015) reported that the CRP was significantly higher in patients with AFI (5.84) than in patients without infected ascites. (2.72).

In the present study, all the CLD cases were diagnosed according to clinical, biochemical, and/or imaging findings. The severity of liver disease was categorized by Child-Pugh's classification: 11 patients $(41 \%)$ were in class B and 16 patients $(59 \%)$ were in class $\mathrm{C}$. The majority of patients had MELD score between $10 \& 19$ (59\%). These results agreed with Abdella et al. (2016) who reported that $55 \%$ of patients were Child-Pugh stage $\mathrm{C}$ and $55.3 \%$ had MELD score between 10 and 19 . Schwabl et al. (2015) reported that $60.7 \%$ of the patients were in Child-Pugh stage $\mathrm{C}$ and their MELD score was 21.2 \pm 9.29 . In the present study, the high frequency of Child score class $\mathrm{C}$ among the patients with infected ascites was 59\%, 55\% in Abdella et al. (2016) and $60.7 \%$ in Schwabl et al. (2015). This might be due to deteriorated liver functions, coagulopathy, elevated bilirubin level and hypoalbuminemia which are common risk factors for AFI in patients with chronic liver disease and ascites.

In the present study, the ascitic cell count was significantly higher in patients with AFI $(550 \pm 865)$ than in patients with non-infected

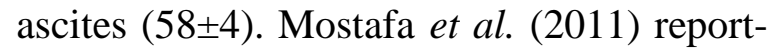
ed that the mean polymorphonuclear count was 211 in patients with AFI and Abdella et al. (2016) found that the mean ascitic cell count was $193 \pm 185$. Also, ascitic fluid LDH was significantly higher in AFI patients $(180 \pm 442 \mathrm{IU} / \mathrm{L})$ than in those without infected ascites $(80 \pm 55 \mathrm{IU} / \mathrm{L})$. While ascitic fluid glucose was significantly lower in AFI patients $(118 \pm 46 \mathrm{mg} / \mathrm{dl})$ than in those without infected ascites $(145 \pm 41 \mathrm{mg} / \mathrm{dl})$. But, the mean ascitic fluid protein and ascitic fluid albumin in patients with AFI were $1.54 \pm 0.81 \mathrm{~g} / \mathrm{dl} \& 1.54 \pm 0.96 \mathrm{~g} / \mathrm{dl}$, respectively. Abdella et al. (2016) found that the mean LDH level was $153 \pm 80 \mathrm{IU} / \mathrm{L}$, total protein was $1.37 \pm 0.52 \mathrm{~g} / \mathrm{dl}$, albumin was $0.63 \pm 0.41$ $\mathrm{g} / \mathrm{dl}$ and glucose was $115.5 \pm 30.94 \mathrm{mg} / \mathrm{dl}$ and Mostafa et al. (2011) found that the mean AF protein was $1.3 \pm 0.5 \mathrm{~g} / \mathrm{dl}$ and albumin was $0.5 \pm 0.2 \mathrm{~g} / \mathrm{dl}$ in patients with AFI.

In the present study, 20 patients had culture negative neutrocytic ascites $(74 \%$ of patients with AFI), 6 patients had monomicrobialbacterascites ( $22 \%$ of patients with $\mathrm{AFI}$ ) and one patient had polymicrobialbacterascites (4\% of patients with AFI). This high frequency of negative cultures can be referred to many factors such as slow growth of the causative organism, low number of organisms, the use of antiseptic dressing before collecting the specimen and the delay in the transport of the specimen. However, these results were consistent with Enomoto et al. (2014) who reported that more than $50 \%$ of patients with infected ascites gave negative ascitic culture and sensitivity despite of the high polymorphonuclear count $(>250$ cells $/ \mathrm{mm} 3)$. These results agreed with Mostafa et al. (2011) who reported that more than $50 \%$ of the patients had negative ascitic culture and sensitivity and $35 \%$ of the patients had bacterascites.

In the present study, the most frequently 
isolated micro-organism was $E$. coli detected in two patients (7\%) followed by Staph. coag neg, Actinobacter spp., Strept. viridans, non-hemolytic Strept, MRSA and Enterococci each was isolated from a patient (4\%). This agreed with Abdella et al. (2016); Koulaouzidis et al.(2007) and Shi et al. (2017) who reported that E. coli was the commonest organism isolated in patients with AFI.

In the present study, the 27 patients with AFI showed significant improvement in ascitic fluid cell count $48 \mathrm{hrs}$ after starting antibiotic treatment where 12 patients responded to the third generation cephalosporins and 9 patients responded to Meropenem (4 patients were resistant to the $3^{\text {rd }}$ generation cephalosporins, 2 patients received Meropenem based on results of ascitic culture and sensitivity and 3 patients received Meropenem empirically because they had nosocomial AFI), 3 patients responded to culture-based Linezolide and one patient responded to culture-based Ciprofloxacin, one patient was resistant to third generation cephalosporin and responded to Piperacillin/ Tazobactam and a patient was asymptomatic nonneutrociticbacterascites who did not receive antibiotic treatment.

\section{Conclusion}

Infection of the ascitic fluid is frequent among patients with chronic liver disease and cirrhosis. Almost one third of ascitic patients developed at least one attack of spontaneous bacterial peritonitis or bacterascites. Abdominal pain was the dominant presentation; however, some patients have mild symptoms that may be overlooked.

Bacteriologic examination of the ascitic fluid is the hallmark for diagnosis of ascetic fluid infection and identified the bacterial type. Monomicrobial-bacterascites was more frequent than polymicrobial-bacterascites and $E$. coli was the commonest isolated organism. The third-generation, broad-spectrum cephalosporins remain a good initial therapy for cephalosporins non allergic patients. Alternative antibiotics such as Meropenem and pipercillin-tazobactam should be considered for patients with nosocomial SBP or for pa- tients who did not improve with traditional antibiotic regimens.

\section{References}

Abdella, HM, Hefny, ZM, Badran, E, Zaki, WK, Ezz El-Arab, H, 2016: Detection of spontaneous bacterial peritonitis in Egyptian cirrhotic patients using culture and 16sRNA based molecular diagnosis. Egypt. J. Med. Lab. Sci. 25, 3: 2-6.

Badawy, AA, Zaher, TI, Sharaf, SM, Emara, MH, Shaheen, NE, et al, 2013: Effect of alternative antibiotics in treatment of cefotaxime resistant spontaneous bacterial peritonitis. Wld. J. Gastroenterol. 19, 8:1271-7.

Brett, F, Andres, C, 2017: Ascites, refractory ascites and hyponatremia in cirrhosis. Gastroenterol. Rep. (Oxford), 5, 2:104-12.

Enomoto, H, Inoue, S, Matsuhisa, A, Nishiguchi, S, 2014: Diagnosis of spontaneous bacterial peritonitis and an in situ hybridization approach to detect an unidentified pathogen. Int. J. Hepatol. 63:4617-9.

Fernández, J, Gustot, T, 2012: Management of bacterial infections in cirrhosis. J. Hepatol. 56: S1-12.

Fiore, M, Maraolo, AE, Gentile, I, Borgia, G, Leone, S, et al, 2017: Nosocomial spontaneous bacterial peritonitis antibiotic treatment in the era of multi-drug resistance pathogens: A systematic review. Wld. J. Gastroenterol. 23, 25: 4654-60.

Gentilini, P, Laffi, G, 1992: Pathophysiology and treatment of ascites and the hepatorenal syndrome. Clin. Gastroenterol. 6, 3:581-607.

Ginès, P, Angeli, P, Lenz, K, 2010: EASL clinical practice guidelines on the management of ascites, spontaneous bacterial peritonitis, and hepatorenal syndrome in cirrhosis. J. Hepatol. 53, 3:397-417.

Juan, A, 2015: Multi-resistant bacterial infections in liver cirrhosis: Clinical impact and new empirical antibiotic treatment policies. Wld. J. Hepatol. 7, 7:916-21.

Koulaouzidis, A, Bhat, S, Karagiannidis, A, Tan, WC, Linaker, BD, 2007: Spontaneous bacterial peritonitis. Postgrad. Med. J. 83, 98:37983.

Mostafa, MS, El-Seidi, EA, Kassem, AM, Shemis, MA, Saber, M,et al, 2011: Detection of ascitic fluid infections in patients with liver cirrhosis and ascites. Arab J. Gastroenterol. 12, 1: $20-4$. 
Runyon, BA, 2009: Management of adult patients with ascites due to cirrhosis: an update. Hepatology 49, 6:2087-107.

Schwabl, P, Bucsics, T, Soucek, K, Mandor fer, M, Bota, S, et al, 2015: Risk factors for development of spontaneous bacterial peritonitis and subsequent mortality in cirrhotic patients with ascites. Liver Int. 35, 9:2121-8.

Sheer, TA, Runyon, BA, 2005: Spontaneous bacterial peritonitis. Dig. Dis. 23, 1:3946.
Shi, L, Wu, D, Wei, L, Liu, S, Zhao, P, et al, 2017: Nosocomial and community acquired spontaneous bacterial peritonitis in patients with liver cirrhosis in China: Comparative microbiology and therapeutic implications. Sci. Rep. Apr 6; 7:46025. doi: 10.1038/srep46025.

Torresi, J, 2017: The rationale for a preventative HCV virus-like particle (VLP) vaccine. Front Microbiol.8:2163. doi:10.3389/fmicb.021502163.

Explanation of figure

Fig. 1: Follow-up after antibiotic therapy showed significant improvement in ascitic fluid cell count

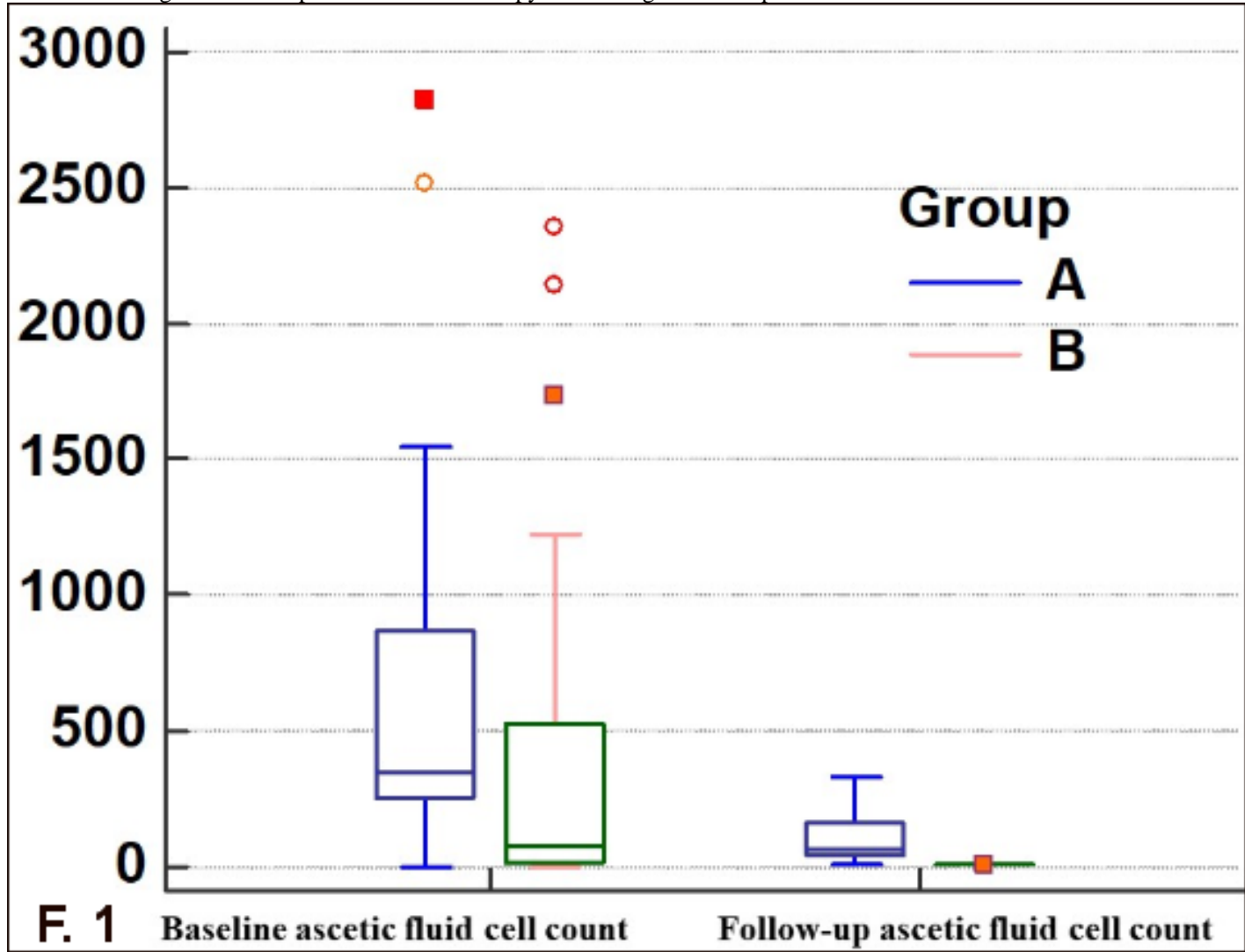

